\title{
ASUHAN MANDIRI PEMANFAATAN TANAMAN OBAT TRADISIONAL DI DESA BUKIAN, BALI
}

\author{
Pande Ayu Naya Kasih Permatananda ${ }^{1}$, I Gede Suranaya Pandit ${ }^{2}$ dan Luh Gede Pradnyawati ${ }^{3}$ \\ ${ }^{1}$ Bagian Farmakologi dan Farmasi, Fakultas Kedokteran dan Ilmu Kesehatan, Universitas Warmadewa \\ ${ }^{2}$ Bagian Manajemen Sumber Daya Perikanan, Fakultas Pertanian, Universitas Warmadewa \\ ${ }^{3}$ Bagian Ilmu Kesehatan Masyarakat, Fakultas Kedokteran dan Ilmu Kesehatan, Universitas Warmadewa \\ Email: nayakasih@gmail.com
}

\begin{abstract}
ABSTRAK. Pemanfaatan tanaman obat tradisional dapat menjadi salah satu upaya pencegahan penyakit, termasuk COVID19. Kegiatan asuhan mandiri pemanfaatan tanaman obat tradisional ini bertujuan untuk meningkatkan pemahaman dan keterampilan masyarakat dalam hal budidaya hingga pengolahan tanaman obat tradisional. Kegiatan diawali dengan wawancara terstruktur terhadap 100 warga desa Bukian untuk mengetahui gambaran penggunaan tanaman obat tradisional di Desa Bukian, dilanjutkan dengan penyampaian materi, diskusi, praktek, dan pendampingan keluarga. Pelaksanaan kegiatan dilakukan secara daring dan luring dengan memperhatikan protokol kesehatan. Evaluasi kegiatan berupa pretest dan postest yang dilakukan terhadap 16 peserta yang mengikuti kegiatan penyampaian materi dan didapatkan rata-rata nilai pretest 4,93 serta nilai postest 7,59. Peningkatan nilai postest dibandingkan pretest bermakna secara statistik (nilai $\mathrm{p}$ $<0.05$ ). Sehingga dapat disimpulkan bahwa kegiatan ini berhasil meningkatkan pengetahuan warga desa Bukian terhadap pemanfaatan tanaman obat tradisional.
\end{abstract}

Kata kunci: tanaman obat tradisional; asuhan mandiri; pengabdian masyarakat; Bali

\begin{abstract}
The use of traditional medicinal plants could be an effort to prevent some diseases, including COVID19. The activity of self training for the use of traditional medicinal plants was aimed to increase community understanding and skills in terms of planting and processing of traditional medicinal plants. This program began with a structurized interview with 100 Bukian villagers to get an overview of the use of traditional medicinal plants in Bukian Village, followed by socialization, discussion, practice, and family mentoring. All activities were carried out online and offline by implementing health protocols. The evaluation was done in the form of pretest and posttest on 16 participants who took part in the seminar. Average pre-test score was 4.93 and post-test score was 7.59. The increase in post-test scores compared to pre-test was statistically significant ( $p$ value $<0.05$ ). Therefore, it can be concluded that this community service succeeded in increasing the knowledge of Bukian villagers on the use of traditional medicinal plants.
\end{abstract}

Keywords: traditional medicinal plants; self training; community development program; Bali

\section{PENDAHULUAN}

Desa Bukian merupakan desa yang terletak di Kecamatan Payangan, Kabupaten Gianyar, Provinsi Bali, Indonesia. Dilihat dari letak geografis Desa Bukian termasuk dataran dengan tinggi 600-700 $\mathrm{m}$ dari permukaan laut beriklim tropis memiliki temperature minimum $23^{\circ} \mathrm{C}$ dan maksimum $32^{\circ} \mathrm{c}$. Desa Bukian memiliki luas wilayah 637,15 ha terletak membujur dari selatan ke utara dengan dibatasi oleh Desa Puhu di sebelah utara, Desa Melinggih di sebelah selatan dan barat dan Desa Taro dan Desa Klusa di sebelah timur. Wilayah Desa Bukian tediri dari 11 banjar yaitu: Banjar Bukian, Banjar Bukian Kaja, Banjar Bukian Kawan, Banjar Subilang, Banjar Lebah A, Banjar Lebah B, Banjar Tiyingan, Banjar Ulapan, Banjar Tangkup, Banjar Amo dan Banjar Dasong. Berdasarkan Website Desa Bukian terdapat 4.103 Jiwa dengan 2.635 jiwa yang berumur diatas 50 tahun (Desa Bukian, 2020).

Dikarenakan sumber daya alam di Desa Bukian sangat melimpah pekerjaan mayoritas warga Bukian adalah petani/pekebun lalu diikuti dengan karyawan swasta dan wiraswasta. Desa Bukian awalnya memiliki masalah dalam air bersih, namun sekarang sudah terdapat kincir air tanpa listrik memudahkan masyarakat untuk mendapatkan air bersih dengan memaksimalkan sumber mata air yang ada. Mayoritas mata pencaharian masyarakat Desa Bukian adalah sebagai petani sawah dan petani kebun atau ladang. Selain dua mata pencaharian tersebut tidak sedikit masyarakat Desa Bukian memiliki hewan ternak seperti babi, sapi dan ayam, dimana hasil ternak tersebut dapat diekspor ke luar wilayah Bukian bahkan bisa juga ke luar daerah Gianyar. Hampir 50\% masyarakat Desa Bukian bekerja sebagai pengrajin dan pegawai swasta diluar daerah Desa Bukian (Desa Bukian, 2020).

Coronavirus (COVID19) merupakan penyakit yang penularannya sangat cepat namun hingga saat ini obatnya belum ditemukan. Berdasarkan data sebaran Dinas Kesehatan Provinsi Bali pada tanggal 26 April 2020 di Bali terdapat 9 kabupaten yang memiliki prevalensi yang beragam diantaranya: 1) Kabupaten Denpasar 46 positif, 17 sembuh, 2 meninggal, dan 27 sedang dirawat ; 2) Kabupaten Bangli 27 positif, 8 sembuh, 0 meninggal, dan 19 sedang di rawat; 3) Kabupaten Buleleng 21 positif, 9 sembuh, 0 meninggal, dan 12 sedang di rawat; 4) Kabupaten 
Gianyar 20 positif, 5 sembuh, 0 meninggal, dan 15 sedang di rawat; 5) Kabupaten Karangasem 15 positiif, 7 sembuh, 0 meninggal, dan 8 sedang dirawat; 6) Kabupaten Klungkung 13 positif, 6 sembuh, 0 meninggal, dan 7 sedang dirawat; 7) Kabupaten Badung 12 positif, 6 sembuh, 0 meninggal, dan 6 sedang di rawat; 8) Kabupaten Jembrana 11 positif, 5 sembuh, 0 meninggal, dan 6 sedang dirawat; 9) Kabupaten Tabanan 9 positif, 6 sembuh, 0 meninggal, dan 3 sedang di rawat (Dinas Kesehatan Provinsi Bali, 2020). Bali merupakan daerah yang sudah terkenal akan pariwisata. Kabupaten Gianyar merupakan salah satu Kabupaten di Bali yang memiliki pusat pariwisata yaitu Ubud dan sekitarnya. Daerah Payangan merupakan salah satu daerah yang dekat dengan Ubud sehingga banyak dibangun hotel, villa, dan tempat-tempat rekreasi di daerah tersebut, oleh karena itu banyak masyarakat Payangan terutama di Desa Bukian yang bekerja di hotel ataupun villa sehingga mereka mudah untuk kontak dengan wisatawan asing. Menurut data dari Dinas Kesehatan Provinsi Bali pada tanggal 26 April 2020, Gianyar menempati kedudukan nomor 4 jumlah kasus COVID-19 tertinggi di Bali. Jumlah orang yang sembuh dari virus corona tidak sebanding dengan orang yang positif virus corona, oleh karena itu upaya pencegahan penyebaran virus corona sangat diperlukan (Dinas Kesehatan Provinsi Bali, 2020)

Untuk mengatasi berbagai penyakit yang ada pada masyakarat, pemerintah Indonesia sejatinya telah menetapkan kebijakan dalam upaya peningkatan pelayanan kesehatan. Sistem Kesehatan Nasional merupakan suatu tatanan yang mencerminkan upaya bangsa Indonesia untuk meningkatkan kemampuan mencapai derajat kesehatan yang optimal sebagai perwujudan kesejahteraan umum (Badan Pusat Statistik, 2008). Salah satunya tercermin dalam penerapan asuhan mandiri pemanfaatan tanaman obat keluarga dan keterampilan budidaya dan pengelolaannya. Asuhan mandiri kesehatan tradisional adalah upaya untuk memelihara dan meningkatkan kesehatan serta mencegah dan mengatasi gangguan kesehatan ringan oleh individu, keluarga, kelompok, dan masyarakat dengan memanfaatkan tanaman obat keluarga dan keterampilan dalam memanfaatkannya (Kementerian Kesehatan Republik Indonesia, 2016). Meskipun sudah tertuang dalam Peraturan Menteri Kesehatan, namun asuhan ini belum digalakkan atau diprogramkan secara merata. Sehingga berkenaan dengan situasi pandemi COVID19, maka tim program kemitraan masyarakat Universitas Warmadewa melakukan kegiatan asuhan mandiri pemanfaatan tanaman obat tradisional di Desa Bukian Kecamatan Payangan dengan tujuan memasyarakatkan pemanfaatan tanaman obat tradisional untuk membantu menjaga kesehatan keluarga di tengah pandemi.

\section{METODE}

Program Kemitraan Masyarakat (PKM) "Asuhan Mandiri Pemanfaatan Tanaman Obat Tradisional" ini terbagi menjadi beberapa tahap kegiatan: dialog dan diskusi singkat terkait tanaman obat tradisional yang pernah dimanfaatkan oleh masyarakat Desa Bukian meliputi jenis bahan/ tanaman, cara pemanfaatan serta tujuan pemanfaatan, sosialisasi terkait pemanfaatan tanaman obat tradisional khususnya yang bermanfaat untuk menjaga kekebalan tubuh di tengah pandemi COVID19 dan cara penanaman/budidaya tanaman obat tradisional, dan diakhiri dengan pendampingan intensif terhadap beberapa keluarga binaan di Desa Bukian. Proses penyampaian materi dilakukan melalui konferensi daring selama satu jam, sedangkan proses diskusi dan praktek dilakukan langsung dengan memperhatikan protokol kesehatan, di mana peserta yang datang dibagi menjadi beberapa kelompok, yang masingmasing kelompok didampingi oleh salah seorang narasumber untuk mendorong partisipasi aktif masyarakat (Permatananda et al., 2020) Proses pendampingan intensif kepada keluarga yang terpilih dilakukan dengan daring untuk melihat sejauh mana aplikasi ilmu yang didapat dan mengulas kembali materi yang diberikan. Tim PKM juga menyerahkan bantuan sejumlah paket tanaman obat tradisional untuk dibagikan kepada masyarakat Desa Bukian kepada Kepala Desa Bukian selaku mitra.

Evaluasi kegiatan didasarkan pada antusiasme peserta yang dilihat melalui kehadiran dan partisipasi peserta saat proses diskusi dan sosialisasi dan peningkatan pengetahuan yang dilihat melalui nilai pre-test dan post-test yang dilakukan sebelum kegiatan dan setelah kegiatan berlangsung. Pre-test dan post-test berisi 10 pertanyaan benar/salah terkait tanaman obat tradisional yang dapat dimanfaatkan keluarga yang materinya berasal dari buku Pedoman Penggunaan Herbal dan Suplemen Kesehatan dalam Menghadapi COVID19 di Indonesia (Badan Pengawas Obat dan Makanan, 2020) yang sudah dijelaskan saat penyampaian materi oleh narasumber. Peningkatan nilai post-test dari pre-test kemudian dianalisis dengan menggunakanujistatistikdenganmenggunakan paired t-test sebagai indikator peningkatan pengetahuan. Evaluasi berkelanjutan sebagai langkah monitoring dilakukan ketika melakukan pendampingan intensif.

\section{HASIL DAN PEMBAHASAN}

Kegiatan PKM 'Asuhan Mandiri Pemanfaatan Tanaman Obat Tradisional' dilaksanakan dari bulan April sampai Mei 2020 bertempat di Desa Bukian, Kecamatan Payangan, Kabupaten Gianyar. Kegiatan PKM ini juga dilakukan serangkaian dengan kegiatan Kuliah Kerja Nyata (KKN) Tematik FKIK 
Universitas Warmadewa. Sebelum kegiatan ini dilakukan, Panitia melakukan wawancara terstruktur kepada 100 warga Desa Bukian untuk mengetahui gambaran pemanfaatan tanaman obat tradisional di Desa Bukian, yang hasilnya dapat dilihat pada Tabel 1. Tabel 1 menyajikan frekuensi terbanyak dari jenis tanaman, cara pemanfaatan, beserta tujuan pemanfaatanya.

Melalui wawancara terstruktur tersebut, diketahui bahwa masyarakat Desa Bukian cukup banyak yang memanfaatkan tanaman obat tradisional untuk menunjang kesehatan. Hal ini sejalan dengan penelitian yang dilakukan oleh Sari et al., pada tahun 2015 yang mengungkapkan bahwa Kabupaten Gianyar merupakan salah satu wilayah di Bali yang warganya cukup aktif melakukan pemanfaatan tanaman obat tradisional. Melalui studi kualitatif tersebut disampaikan bahwa tanaman obat tradisional yang dimanfaatkan biasanya merupakan tanaman rempah bumbu dan digunakan sebagai obat sakit ringan yang dapat dilakukan sendiri oleh warga tanpa menunggu tenaga kesehatan profesional. Selain itu ada juga warga yang membudidayakan tanaman obat sebagai sumber penghasilan, bahkan di Bali bunga dari tanaman obat tradisional dapat menjadi bagian dari sarana upacara dan sembahyang. Meskipun pemanfaatan tanaman obat tradisional di Gianyar cukup aktif, namun implementasinya dalam program Tanaman Obat Keluarga (TOGA) masih belum maksimal yang disebabkan karena masyarakat tidak benar-benar memahami manfaat tanaman obat tradisional hanya berdasar pengalaman turunmenurun ditambah dengan kurangnya sosialiasi dari petugas kesehatan setempat, yang tentunya hal ini akan sangat bergantung dengan kebijakan kepala desa setempat (Sari et al., 2015). Jika melihat pada buku Pedoman Penggunaan Herbal dan Suplemen Kesehatan dalam Menghadapi COVID19 di Indonesia, tanaman obat tradisional yang dapat digunakan adalah kunyit, jahe, temulawak, daun jambu biji, buah jambu biji, meniran, dan sambiloto (Badan Pengawas Obat dan Makanan, 2020), di mana kunyit (59\%), jahe $(55 \%)$, dan temulawak (3\%) termasuk dalam sepuluh tanaman terbanyak yang dimanfaatkan oleh warga Desa Bukian untuk tujuan kesehatan. Jahe merupakan tanaman obat tradisional yang paling banyak digunakan di Desa Bukian dalam mengatasi berbagai jenis gangguan kesehatan, terutama paling banyak digunakan untuk menghangatkan badan. Jahe terutama jahe merah bermanfaat sebagai anti radang (Levita et al., 2020). Selain sebagai anti radang atau anti inflamasi, jahe dikatakan memilikiaktivitas sebagai imunomodulator sehingga diperkirakan dapat memiliki manfaat dalam menghadapi COVID19 (BPOM, 2020). Selain jahe, kunyit dan temulawak juga memiliki kemampuan serupa (Permatananda et al., 2020; BPOM, 2020).

Untuk menilai keberhasilan program, maka dilakukan pre-test sebelum dilakukan pemberian materi dan setelah diskusi, diakhir sesi dilakukan postest. Soal pre-test dan post-test merupakan 10 pertanyaan benar/salah seputar materi yang sudah diberikan, meliputi: COVID19, tanaman obat tradisional yang dapat dimanfaatkan untuk mencegah COVID19, cara pemanfaatannya, kandungan tanaman obat tradisonal, memilih herbal dan suplemen kesehatan, perbedaan jamu, herbal, dan fitofarmaka, serta cara penanaman tanaman obat tradisional. Rata-rata nilai pre-test dari 16 peserta adalah 4,93 dan rata-rata nilai post-test adalah 7,56 dengan hasil uji statistik melalui paired t-test didapatkan nilai $\mathrm{p} 0,001$ yang bermakna signifikan, dapat dilihat pada Gambar 1. Dengan demikian dapat disimpulkan bahwa kegiatan yang dilakukan atau materi yang diberikan mampu meningkatkan pengetahuan warga Desa Bukian terkait pemanfaatan tanaman obat tradisional. Meskipun materi diberikan secara daring karena situasi pandemi, namun efektifivitas penyampaian materi kepada peserta tetap terjaga (Raharja et al., 2020).

Untuk menjamin bahwa materi yang disampaikan dapat diaplikasikan di rumah, maka dilakukan pendampingan sekaligus monitoring pada keluarga yang menjadi keluarga Binaan Fakultas Kedokteran

\section{Tabel 1. Sepuluh Tanaman Obat Tradisional Terbanyak yang Dimanfaatkan Warga Desa Bukian}

\begin{tabular}{clll}
\hline No & \multicolumn{1}{c}{ Jenis tanaman } & \multicolumn{1}{c}{ Cara Pemanfaatan } & \multicolumn{1}{c}{ Tujuan Pemanfaatan } \\
\hline 1 & Jahe $(59 \%)$ & Direbus $(52 \%)$ & Menghangatkan badan (48\%) \\
2 & Kunyit (55\%) & Direbus (20\%) & Mengeringkan luka (15\%) \\
3 & Sirih (22\%) & Direbus (17\%) & Menjaga kesehatan reproduksi wanita (13\%) \\
4 & Kencur (12\%) & Dibuat boreh (12\%) & Menghangatkan badan (8\%) \\
5 & Kumis Kucing (7\%) & Direbus (6\%) & Melancarkan kencing (3\%) \\
6 & Binahong (7\%) & Dibuat jamu/loloh (5\%) & Menurunkan tekanan darah (3\%) \\
7 & Lidah Buaya (6\%) & Dipakai langsung (5\%) & Menguatkan rambut (5\%) \\
8 & Beluntas (4\%) & Dibuat jamu/loloh (3\%) & Menghilangkan bau badan (3\%) \\
9 & Temulawak (3\%) & Direbus (3\%) & Menurunkan tekanan darah (2\%) \\
10 & Pepaya (3\%) & Dihaluskan (3\%) & Melancarkan pencernaan (2\%) \\
\hline
\end{tabular}


Universitas Warmadewa. Pendampingan dilakukan dengan metode daring dan tatap muka. Pendampingan tatap muka terutama dilakukan untuk penanaman tanaman obat tradisional pada pekarangan rumah keluarga, sedangkan pendampingan daring dilakukan untuk meninjau dan berdiskusi terkait kendalakendala yang dialami warga dalam pengolahan tanaman obat tradisional. Melalui pendampingan tersebut didapatkan bahwa untuk mengolah tanaman obat tradisional seperti merebus atau membuat jamu/ loloh tidaklah sulit, hanya saja masyarakat lebih suka jika ada yang lebih praktis mengingat kesibukan warga, dan jamu/loloh yang dihasilkan seringkali tidak bertahan lama sehingga belum terpikir untuk mengembangkan menjadi produk komersil.

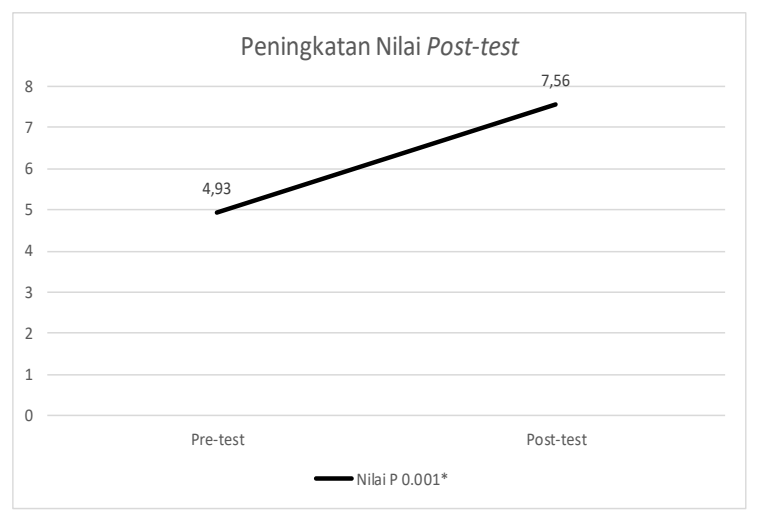

Gambar 1. Rata-rata Nilai Tingkat Pengetahuan pada Saat Pre-test dan Post-test

\section{SIMPULAN}

Kegiatan asuhan mandiri pemanfaatan tanaman obat tradisional diDesa Bukianyang berlangsung di tengah pandemi COVID19, sehingga metode kegiatan dilakukan secara kombinasi antara daring dan luring dengan tetap menjaga protokol kesehatan. Kegiatan ini dilakukan untuk meningkatkan pemahaman warga Desa Bukian terhadap pemanfaatan tanaman obat tradisional dengan harapan warga Desa Bukian dapat menggunakan tanaman obat tradisonal secara mandiri untuk menjaga kesehatan keluarga di tengah pandemi COVID19. Melihat dari nilai pre-test dan post-test didapatkan bahwa kegiatan ini berhasil meningkatkan pengetahuan warga Desa Bukian terkait tanaman obat tradisional. Pendampingan dilakukan secara berkelanjutan hingga warga menjadi mandiri dalam melakukan pengolahan tanaman obat tradisional.

\section{UCAPAN TERIMAKASIH}

Kami mengucapkan terima kasih kepada Lembaga Pengabdian MasyarakatUniversitas Warmadewa atas dukungan yang diberikan sehingga kegiatan dapat terselenggara. Tidak lupa terima kasih juga diberikan kepada tim pelaksana PKM, Kepala Desa, dan warga Desa Bukian yang telah berpartisipasi, beserta seluruh civitas akademika Universitas Warmadewa yang turut membantu dalam pelaksanaan kegiatan.

\section{DAFTAR PUSTAKA}

Badan Pengawas Obat dan Makanan, 2020. Pedoman Penggunaan Herbal dan Supplemen Kesehatan dalam Menghadapi COVID19 di Indonesia. Jakarta: Badan Pengawas Obat dan Makanan.

Badan Pusat Statistik. 2008. National Family Planning Coordinating Board, Ministry of Health, ORC Optimalisasi Peran Sains dan Teknologi untuk Mewujudkan Smart City. Jakarta: Badan Pusat Statistik.

Desa Bukian. 2020. Website Resmi Desa Bukian Kecamatan Payangan Kabupaten Gianyar Provinsi Bali. (http://desabukian.zeta.co.id, diakses 25 April 2020)

Dinas Kesehatan Provinsi Bali. 2020. Data Sebaran Kasus COVID19 di Bali. (https://pendataan. baliprov.go.id, diakses 26 April 2020).

Kementerian Kesehatan Republik Indonesia, 2016. Peraturan Menteri Kesehatan Nomor 9 Tahun 2016 tentang upaya pengembangan kesehatan melalui asuhan mandiri pemanfaatan tanaman obat keluarga dan ketrampilan budidaya dan pengolahannya. Jakarta: Kementerian Kesehatan Republik Indonesia.

Levita, J., Sumiwi, S.A., Mutakin, M., Milanda, T., Puspitasari, I.M., Andriani., Y., Febrina, E., Amalia, R., Rosdianto, A.M., Muhtadi, A. 2020. Pemeriksaan Kesehatan dan Penyuluhan Pemanfaatan Jahe Merah Sebagai Tanaman Berkhasiat Antiradang Bagi Kader PKK di Desa Cikidang Kecamatan Lembang. Dharmakarya. 9(2) 65-69.

Permatananda, P.A.N.K., Aryastuti, A.A.S.A., Cahyawati, P.N., 2020. Gerakan Keluarga Sadar Obat pada Kelompok Wanita dengan Pendekatan Belajar Aktif. Jurnal Pengabdian Kepada Masyarakat. 6(1).

Permatananda, P.A.N.K, Aryastuti, A.A.S.A., Cahyawati, P.N., Udiyani, D.P.C., Pandit, I.G.S., Wirajaya, A.A.N.M.2020. Phytochemical and Antioxidant Capacity Test on Turmeric Extract (Curcuma longa) Traditionally Processed in Bali. Jurnal Bali Membangun Bali. 1(2) 135-142. 
Sari, I. D., Yuniar, Y., Siahaan, S., Riswati, Syaripuddin, M., 2015. Tradisi Masyarakat dalam Penanaman dan Pemanfaatan Tanaman Obat Lekat di Pekarangan. Jurnal Kefarmasian Indonesia. 5(2) 123-132.
Raharja, S.J., Chan, A., Kostini. N., Muhyi, H.A. 2020. Pelatihan Pemasaran Online Produk Industri Kreatif di Desa Laksana Mekar, Kecamatan Padalarang, Kabupaten Bandung Barat. Dharmakarya. 9(2) 93-96. 